\title{
ASEAN Way in Korean Peninsula Peacebuilding
}

\author{
Idham Badruzaman ${ }^{1}$, Rafyoga Jehan Pratama Irsadanar ${ }^{2}$ \\ ${ }^{1}$ Department of International Relations, Faculty of Social and Political Sciences, Universitas \\ Muhammadiyah Yogyakarta, Yogyakarta, Indonesia| Department of Modern History, Faculty of \\ Philosophy and Arts, Universidad Autónoma de Madrid, Spain \\ 2 Department of International Cooperation Policy Studies, Graduate School of International \\ Cooperation Studies, Kobe University, Hyogo Prefecture, Japan \\ idham bz@umy.ac.id, ${ }^{2}$ irsadanar.rafyoga@gmail.com
}

\begin{abstract}
This article aims to analyze the role of ASEAN in peacebuilding and soft diplomacy to mediate North and South Korea and to contribute to peacekeeping in the region. As stated by Johan Galtung, one fundamental principle in establishing peace is to involve the conflicting parties into a constructive dialogue. By this principle, ASEAN avoids isolative policy by officially welcoming Pyongyang in ASEAN Regional Forum (ARF) in 2000 and cultivating a trustworthy relationship afterwards. Driven by ASEAN Fundamental Principle in The Treaty of Amity and Cooperation (TAC) 1976, ARF appeared to be effective to maintain North Korea in negotiating table, as it also remains to be the only multilateral framework North Korea is in. This ASEAN soft diplomacy in peacebuilding also gains the positive support by Seoul as the engagement with ASEAN through its new southern policy intensifies. With ASEAN contribution as neighboring regional organization, many progresses of peacebuilding, such as Panmunjom Agreement, could be achieved. This paper analyses the role of ASEAN through its way of peacebuilding and soft diplomacy in mediating two Koreas and to help in maintaining peace in the region. This paper finds out that ASEAN's impartiality and traditional friendship among ASEAN members and two Koreas are the keys of ASEAN role in this regard. The findings of this research signify the importance of soft diplomacy in peacebuilding, as many big powers such as United States and China were failed to approach North Korea by using power projection and coercion.
\end{abstract}

Keywords: Peacebuilding, ASEAN Fundamental Principle, Dialogue, Korean Peninsula.

\section{INTRODUCTION}

When Japanese occupation ended in 1945, Korean Peninsula was subjected to the sovereign of the World War 2 victors, North Korea was controlled by Soviet Union and South Korea by the United States. Short after the division by $38^{\text {th }}$ parallel, Pyongyang, backed by Moscow, invaded its southern counterpart aiming to expand its territory. That was the moment when Korean War broke out, which resulted a military stalemate instead of an official end. When Soviet Union fell in 1991, North Korea had to stand up by itself in the post-cold war era where communist domination started to fade away. In the aftermath, North Korea continued developing the nuclear projects that were initiated by Soviet Union in late 1950s. Such projects involve nuclear warheads, which has induced anxiety among its neighbors and the global community for decades.

As stated by Johan Galtung, one fundamental principle in peacebuilding is for the conflicting parties to engage in a constructive dialogue. By this principle, ASEAN welcomed Pyongyang in ASEAN Regional Forum (ARF) in 2000 and maintains the good relationship afterwards. ARF is driven by ASEAN Fundamental Principle in The Treaty of Amity and Cooperation (TAC) 1976, and appears to be progressive to keep North Korea in the negotiating table. By far, ARF remains the only multilateral framework North Korea participates in. Soft diplomacy such as this wins positive 
supports from Seoul especially when the engagement between ASEAN and South Korea has positive outlooks. ASEAN as a regional organization drives changes and allows the progression of peacebuilding, such as the achievement of Panmunjom Agreement.

This article aims to analyze the role of ASEAN in peacebuilding and soft diplomacy to mediate North and South Korea and to contribute to peacekeeping in the region. The role is less powerful compared to major actors i.e. United States, China, Japan and Russia. This paper explores the implementation of "ASEAN Way" that focuses on peaceful resolution and non-interference principle written in TAC 1976. This paper argues that impartiality and traditional friendship among ASEAN members and North and South Korean are important success factors behind ASEAN's success.

\section{LITERATURE REVIEW}

Theoretically, in peace studies, powerful countries are often successful in mediating conflicting parties and lead them into peace agreements (Favretto, 2009). However, powerful states such as United States and China do not find it easy to pacify North Korea, as suggested by the failure of Security Council sanctions and Six Party Talk, especially when coercion/power is involved in sending the message. This research aims to corroborate this assumption and extend the understanding of ASEAN's role by exploring the power of soft diplomacy. Such role is of interest because the power status of the mediating state i.e. ASEAN is weaker than the US and China. The findings are expected to provide policy makers' an alternative to settle international or bilateral disputes similar to what happens in Korean Peninsula.

\section{RESEARCH METHOD}

This research utilized qualitative method to explain the role of a regional organization in supporting the peacebuilding process. The secondary data amassed are comprised of ASEAN official documents and current affairs trends, as well as historical records. The concept of soft power and peacebuilding are then used to analyze the documents, answering the research objectives.

\section{THEORETICAL FRAMEWORK}

This paper has at least two fundamental scholars whose theories are mainly used to analyze the topic, Johan Galtung and John Paul Lederach. When it comes to and old thinking, Johan Galtung started the study of peace quite early even before the peace and conflict studies become popular around that time, and that is what made him called the founding father of its discipline.

Galtung coined the terms of positive and negative peace where negative peace simply means the absence of war while positive peace means beyond that, and it take people to move up into the next level such as restoration of relationship or creation of social system that serves people better. This level of peace implicates the needs of the stake holders to fill the negative peace with something more for the improvement of social life. However, peace does not mean the total absence of conflict because according to John Paul Lederach, conflict is normal in human relationships and conflict is a motor of change. Conflict transformation is a term where Lederach finds it accurate 
because transformation according to him is goes beyond the resolution of the particular problem. The key to transformation is the capacity to envision conflict as having the potential for constructive change. Lederach sees conflict in a very positive way as he believes that conflict happens for a reason. So, not the conflict that we should avoid, instead the violence that is supposed to be anticipated. This way, conflict can function as a motor of change, new opportunities and the reason.

Communication is very important between parties when they encounter a conflict. Failing to make an effective communication, might possibly lead them end up in violence or war. Galtung emphasized that all parties should be in involved in dialogue. There should not be any party excluded from such a dialogue. Perhaps it sounds very normative, but in fact, there are many conflict events in the world excluding some conflicting parties while engaging with some other parties that are in favor to them. In other words, the concept is simple yet some parties find it difficult to be implemented. As mediator, a party shall be impartial and ensure all parties are included in a dialogue.

As for Lederach, conflict is positive and has a great potential to be transformed into something constructive. Therefore, the spirit that is built within stakeholders are respecting one to another. Maintaining friendship and work together is one of the values of respect to keep conflict remains potential not dismissal and keep it as a motor of constructive change not a trigger of destructive act.

\section{RESULT AND DISCUSSION}

\section{THE RELATIONSHIP BETWEEN ASEAN AND THE TWO KOREAS}

As an established regional organization, ASEAN's engagement with its surroundings has been positive, e.g. the involvement of non-ASEAN states within ASEAN frameworks, such as ASEAN+3 and ASEAN Regional Forum. The bilateral relationships among ASEAN members themselves are good, as well as the relationship between the members and the neighbors, such as North and South Korea. North Korea has made many "traditional friends" in ASEAN, whereas President Moon of South Korea recognizes ASEAN as a "fifth power" in his New Southern Policy. This subchapter aims to elaborate the political capital of ASEAN as the bargaining power to participate in Korean Peninsula peacebuilding talk.

1) The "Traditional Friendship" between ASEAN and North Korea

Contrary to popular beliefs, North Korea takes interest in building strong and lasting relationship with other political entities, including ASEAN. Because of its importance as an economic and political partner, ASEAN is considered as a "traditional friend" by North Korean officials, Asia Times reported (Dunne, 2018). Also, North Korea presumably shares similar ideas with socialistcommunist countries in the region, such as Vietnam, Cambodia, Lao PDR, Myanmar and Old-Order Indonesia.

North Korea's solidarity with Vietnam has been growing since the Vietnam War (Young, 2019). During that period, Kim II Sung supported North Vietnam by mobilizing volunteers from North Korea to the Vietnam War to challenge the United States presence in the country. Kim II Sung even persuaded Moscow to 
provide greater assistance for North Vietnam (Journal of Soviet Ambassador to the DPRK A.M Puzanov for 31 August 1957, 1957).

Still during the Cold War, Kim II Sung also had a close personal tie with King Norodom Sihanouk, which helped advancing North Korea and Cambodia bilateral relationship under the communist-socialist ideology. Besides building a palace for Sihanouk in Pyongyang, North Korea also funded and supported the establishment of Angkor Panorama Museum, including ordering the involvement of artists from the famous North Korean Mansudae Art Studio (Bhati, 2017). Later in 2017, during the escalating tension in Korean Peninsula, North Korean ambassador also stated that Cambodia, as a friend of North Korea, would assist the peacebuilding in the Peninsula by garnering supports from ASEAN countries (Vannarith, 2019).

As for Lao PDR, North Korea has been a good friend since the establishment of their bilateral diplomacy on 24 June 1977. Lao PDR Head of Institute of Foreign Affairs (IFA), Mr. Khamsuay Keodaravonng, stated that Lao PDR and North Korea are good friends and comrades under the same ideology (Sengdara, 2019). Also in 1977, North Korea National Court signed a MoU with Lao People's Supreme Court, aiming to foster "exchange and cooperation in the field of the judiciary" and grow a warmer bilateral relationship under Kim Jong Un's leadership (Zwirko, 2019). Considering the growing cooperation, it is being predicted that both countries will maintain a close relationship.

Another country in ASEAN that shares a similar situation as the North Korea, i.e. under United Nations sanctions, is Myanmar. The relationship of the two countries began to flourish in 1962 when North Korea's Kim II Sung and Myanmar's Ne Win started to reach out to each other due to the similar believe that both of them are in the same boat against imperialism. In result, besides the growing trade relationship, the bilateral relationship is maintained even after Yangon started a bilateral connection with Seoul in mid-1970s (Ahn, 2010). In fact, since 2010, Myanmar is listed in North Korea's export destinations (Haggar, 2010).

Even though the contemporary Indonesia, post the New Order era, is rather distant from communist-socialist ideology, the image of the Old Order's Soekarno remains good in North Korea's memory. Kim II Sung and Soekarno had a strong bond. After the official diplomatic establishment in 1960s, Indonesia and North Korea remain a close partner that respect each other. In fact, in 2015 Soekarno Center awarded Kim Jong Un a statesman award to appreciate his leadership (Rivett-Carnac, 2015).

2) ASEAN: The "Fifth Power" in South Korea Policy

The engagement between South Korea and ASEAN after the Korean War has been steadily advancing in many sectors. The connection extends to major multilateral frameworks such as ASEAN+3 and ARF. The diplomatic link among the two is maintained despite the tension in the region. The relationship has survived the tension resulting from Cold War and a series of economic crisis. 
Previously, South Korea had enhanced the New Northern Policy aiming to tighten the relation with northern countries such as Russia, Japan, Mongolia and China. Under Moon Jae-in presidency, ASEAN strategic importance was taken more seriously. In fact, during his visit to Jakarta, the President introduced New Southern Policy to ASEAN audience, aiming to expand the diplomacy beyond the northern hemisphere (Ariffin, 2019). In the context of Korean Peninsula conflict, South Korea considers ASEAN as the fifth power in deescalating tension after United States, Japan, Russia and China (Jaehyon, 2019).

Politically, ASEAN and South Korea have been very close, especially after the two parties became official dialogue partners in the 1991 ASEAN Ministerial Meeting Kuala Lumpur (Overview of ASEAN-Republic of Korea Dialogue Relations, 2020). Ever since, through ASEAN-led multilateral frameworks such as ARF, ASEAN+3, East Asian Summit and ASEAN Defense Ministerial Meeting, South Korea has led many initiatives in political-security sectors, such as maritime security and disaster management. The relationship is fostered by the fact that both ASEAN and South Korea share similar geopolitical location, that is in the middle of powers clash between the United States and China (Ariffin, 2019).

In terms of economy, ASEAN is the second largest trading partner of South Korea under Korea-ASEAN Free Trade Agreement (Ha, Chung, \& Seo, 2016). Not only that the trade flow is large, but is also accelerating quickly. In 2015, the trade volume was USD 155 billion, rising by $22.8 \%$ from the previous year (Overview of ASEAN-Republic of Korea Dialogue Relations, 2020). The steep increase also occurred in the investment sector. The USD 1.5 billion of South Korean investment in 2008 went up threefold to USD 4.5 billion in 2014 (Jae-kyoung, 2016).

\section{ASEAN WAY AND PEACEBUILDING IN KOREAN PENINSULA}

ASEAN has been maintaining peace and stability in the region since its establishment in 1967. Indeed, the purpose of the establishment was to build peace in the region. Prior to this, the founding fathers of ASEAN were often in disputes, such as Singapore and Malaysia regarding their bitter separation, and the case of Indonesia and Malaysia with their open confrontation (Mahbubani \& Sng, 2017). When the stability of the Southeast Asia became relatively stable, ASEAN started to reach a bigger scope which is regional (and even international) by establishing the ASEAN Regional Forum (ARF) in 1994. Not only those countries in the Asia-pacific region are included in the ARF, but also all strong countries in the world such as United States of America, Russia, People's Republic of China, Japan, and European Union. With the objective "to foster constructive dialogue and consultation on political and security issues of common interest and concern; and to make significant contributions to efforts towards confidence-building and preventive diplomacy in the Asia-pacific region" (ASEAN Regional Forum (ARF), 1994), ARF becomes a major vehicle for realizing ASEAN's goal in creating and maintaining regional stability and harmony, including to help the two Koreas in breaking the silence, obviously with the ASEAN way. 
A year after ASEAN established the ARF, Vietnam joined the ASEAN on 28 July 1995. Followed by Lao PDR and Myanmar on 23 July 1997, and Cambodia on 30 April 1999, making up what are today the ten member states of ASEAN. As above communist states joined the ASEAN, it made ASEAN even stronger in a way that ASEAN become more diverse and has a capital to engage with other communist states in Asia-pacific region, including the North Korea. This sub-chapter will elaborate the potential capability of ASEAN in pacifying the Korean peninsula with the ASEAN way.

1) ASEAN and Peace Principles

ASEAN fundamental principle is to build sustainable relationship among ASEAN members as well as to acknowledge the existence both negative and positive peace in the region. According to Johan Galtung, the founding father of Peace Studies, negative peace means the absence of war, whereas positive peace extends to restoration of friendship, the improvement of well-being, and the culture of cooperation, dialogue, peace, equality and justice (Galtung, 1996; Webel \& Galtung, 2007).

Positive peace is unlikely to be achieved unless the negative peace is achieved. The first five points of ASEAN fundamental principles support the negative peace and the last point supports the positive peace. In other words, there are five principles to avoid the negative peace and to allow the creation of positive peace, and there is one point to foster the positive peace.

John Paul Lederach views conflict as natural and occurs in everyday life (Lederach, 2003). Kenneth Kaye and Lederach agree that conflict is an opportunity that can transform the conflicting parties for the better (Kaye, 1997). However, if conflict turns into violence, then it is not constructive change that is made but destruction and loss instead. Therefore, the fundamental principles of ASEAN (especially point number four and five) ensure that any conflict in the region will not go beyond. ASEAN wishes to keep the conflict as productive as it could be and would not let it shake the harmony and stability in the region.

ASEAN always attempts to put the principles into practice, especially the last point, so that positive peace can be developed. ASEAN has been progressing well in promoting cooperation among its member states such as by establishing the ASEAN Community 2015 with three pillars of cooperation: Political Security Community, Economic Community, and Socio-Cultural Community. Previously, ASEAN established ASEAN Humanitarian Assistance (AHA), a disaster management organization to respond to emergency in ASEAN countries.

ASEAN is committed to keep peace and stability in the region and not to participate in any conflict among global powers. This is expressed in Kuala Lumpur Declaration in 1971 known as Zone of Peace, Freedom and Neutrality (ZOPFAN). Consequently, ASEAN would not be taking sides on the current issue of trade war between the US and China as PM Lee Hsien Loong stated during the $34^{\text {th }}$ ASEAN Summit in Bangkok, ASEAN countries are not taking sides on this issue (Au-Yong, 2019). In fact, to ensure that the region is safe from the threat of massive destruction weapon, all ASEAN leaders have made a legitimate regulation called the Southeast Asian Nuclear Weapon Free Zone 
(SEANWFZ). This came into effect in 1995 and has cleared ASEAN countries from any use of weapon of mass destruction.

Despite the close cooperation, ASEAN does not interfere internal affairs of its members. This is part of the fundamental principles referred to as 'noninterference policy'. The principle requires ASEAN members not only to respect and treat each other equally but also to leave internal problem in the hands of home affair officials or relevant internal stakeholders. ASEAN will provide aid if needed but will avoid unnecessary interference. ASEAN is aware of the problems faced by its members but will not interference unless it deals with the humanitarian crisis. Even so, the interference will not be more than soft diplomacy, advises and humanitarian assistance. For instance, during the Rohingya crisis in Myanmar, the Indonesian government represented by the foreign minister, Retno Marsudi, visited Myanmar and offered humanitarian aid from Indonesian government and some other non-governmental donors such as Muhammadiyah and Nahdlatul Ulama. In addition, to show more on how ASEAN works in a very soft diplomacy, Indonesian Government handed a grant of 7.5 billion Rupiah during the $34^{\text {th }}$ ASEAN Summit in Bangkok to help repatriate the Rohingya Refugees from Cox's Bazar, Bangladesh to Myanmar (Bhwana, 2019). The ASEAN way, according to the former secretary-general of ASEAN, Rodolfo C. Severino, is quiet, carried out through soft diplomacy, and is far from megaphone or feel-good diplomacy (Severino R. C., 2001). Although progress is not apparent on the face of it, but people will benefit from the result eventually.

\section{PRACTICES AND PROGRESSES}

This subchapter aims to elaborate the significance of ASEAN's engagement in Korean Peninsula that was guided by the ASEAN principles, hence argues about the significance of "ASEAN Way" in peacebuilding. This includes the peacebuilding practices namely facilitating, mediating and initiating new proposals as the manifestation of the ASEAN Way. The analysis would then measure how far the peace-making have progressed as the result of ASEAN involvement.

1) Facilitating Role

ASEAN facilitates dialogues mainly through ARF (ASEAN Regional Forum) where problems are handled effectively and misunderstanding can be avoided. ARF can also function as a forum that provides space for interaction among its members. In this forum, ASEAN provides an ideal example of what Johan Galtung refers to as inclusive dialogue (Galtung, 2000). Each ASEAN member state is equal and has the same right. There is no veto right that privileges one member and subsides the others. ASEAN welcomes any state in the region to join regardless the differences, such as Vietnam with its communist background. As a new member, Vietnam (and other countries that joined recently) have neither different right nor receive different treatment compared to its counterparts in ASEAN. Every state has an equal voice and one vote. 
It is commonly known that ASEAN Regional Forum is the only multilateral framework North Korea is participating in for peace dialogue. However, this framework actually went beyond a round table talk by stimulating many bilateral meetings. In 2018, Singapore hosted DPRK-U.S Summit where Kim Jong-Un and Donald Trump made historic meeting by discussing Korean Peninsula denuclearization in person. North Korea thanked Singapore, which was ARF Chair, for hosting the Summit and recognized the meeting as part of ASEAN Regional Forum role in achieving peace and stability in the region (Annual Security Outlook, 2018).

In aftermath, the meeting was able to pacify the tension between North Korea and United States, regardless of the remaining work to be done by both parties. The progress was seen to have "freeze for freeze" nuance between Trump and Kim, in reflecting that United States willing to freeze its military presence in South Korea will lead to North Korea freezing its nuclear project (Fisher, 2018). Singapore, chairing ASEAN and hosting the meeting, was seen to be the honest broker as it holds 2008 U.S-North Korea talk on Pyongyang Nuclear issue, making it the good neutral venue (Wong, Venkat, \& Cheng, 2018). For ASEAN itself, it solidified and signified the Association's role in the Korean Peninsula peacebuilding.

However, as it is stated in the beginning of this article, the ASEAN way works very slowly but it does work. There must be a first step among many steps toward peace in any cases, and it was not easy to materialize the first few steps.In the context of North Korea, it obviously was not easy to step-in in a dialogue as it has been very isolative, sanctioned of many by the United Nations, regional organizations and countries around the world, and at the same time North Korea holds confidence of power through its nuclear program. The meeting in Singapore between Trump and Kim Jong Un shows a clear highlight that US has shifted its model of diplomacy to a soft diplomacy, a model that has been practiced and promoted by ASEAN through its ASEAN way. The move was highlighted that the US should not continue with its coercive policy towards North Korea.

The meeting in Singapore (12 June 2018) was not the only meeting held, there were two more summits between North Korea and the US afterwards, the two days summit was held in Hanoi (27-28 February 2019) and the third summit was held in Korean Demilitarized Zone/DMZ (30 June 2019). The above summits were just few among many steps towards (positive) peace in the region (and globally). We should be fair to see that (negative) peace have been in place for decades, while peacebuilding attempts have been done by parties related. The progress would not be seen so quickly but on the other hand, we should not be skeptical or pessimistic as that how ASEAN way works, slowly but sure. Furthermore, the meetings above were not useless at all even the tension raised again in June 2020 as John Paul Lederach believes that things happen for a reason. 
2) Mediating Role

In the context of Korean Peninsula tension, ASEAN soft power diplomacy is significant in reducing conflict by engaging with North Korea, owing to (1) ASEAN traditional friendship with North Korea and (2) ASEAN neutrality in the peacebuilding discourse. These two factors help building trust between North Korea and ASEAN, resulting in political advancement in the Peninsula. By this trust, ASEAN could appear as mediating actor since it could engage to both North Korean and other countries' side in equal bargaining level.

ASEAN's good relationship with North Korea is relatively more successful than the major powers' attempted friendships. ASEAN is able to maintain a communist-socialist cultural bond with North Korea, forming "traditional friendship" which functions as cultural resource for its soft power. This cultural bargaining indeed correlates directly with the political value of the soft power. ASEAN regionalism means political openness to all values, including socialistcommunist. In addition to this, ASEAN avoids direct intervention to its members' internal problems, leaving a good impression because it respects sovereignty. ASEAN's neutrality is maintained although it is surrounded by many great powers, including China and the United States. Therefore, North Korea trusts ASEAN neutrality and accountability.

ASEAN appears to be a mediating linchpin due to its ability to engage to both sides. In 2016, after Pyongyang contacted President Duterte (as ASEAN Chairman) to help reducing global major powers' pressure on North Korea, Duterte actually called President Trump and President Xi Jinping as a real follow-up action (Heydarian, 2017). Therefore, unlike Six Party Talks, ARF remains the only multilateral framework, outside the UN, that North Korea participates in (Salim, 2017). While major powers, such as United States was only able to meet North Korea in high-level summits, North Korean government periodically invites ASEAN Committee in North Korea for dialogue in many occasions, such as Kim Jong-Un leadership anniversaries, friendly dinners and official receptions, including ones celebrating ASEAN anniversaries. Concerning the nuclear projects, North Korea is comfortable enough to also invite ASEAN Committee for briefing session about the deployment of ICBM Hwasong-14 in 2017, allowing ASEAN to access the first-hand nuclear projects information and hearing Pyongyang perspective (A situation briefing for the diplomatic envoys of the ASEAN member states resident in the DPRK held, 2017). By using these metrics, the role of ASEAN in Korean Peninsula peace talk will be more and more strategic in the future.

3) Progress

Some researches such as one done by Nah (2017) stated that ASEAN should project more assertive economic and political pressure to North Korea so it could progressively denuclearize. This way may rationally work, but this argument also has to consider that the main reason of North Korea developing its missiles is due to the insecurity of foreign powers pressures, as North Korean government often emphasis on its official statements. As one of the 
largest economies in the world, ASEAN could have opted for the hard diplomacy approach to North Korea akin to the approaches taken by world major powers, such as by imposing economic embargo. ASEAN soft power diplomacy in Pyongyang has been proven to be more effective than the hard power approach in denuclearizing North Korea. By definition, soft power, according to Nye (2008), is an ability to shape the other party's opinion and move its actions towards achieving its own interest through the projection of culture, values and policies. Nye further argues that there are three components of a country's soft power: (1) the attractiveness of its culture to others; (2) the ability to live up to its political values in running the country and (3) the legitimacy and ethics of its foreign policies. By using these metrics, ASEAN's power to exercise soft diplomacy could be measured.

ASEAN is a culturally diverse region with 600 million population across 10 countries. President Moon Jae-in, in his lecture in Singapore in 2018, praised the admirable way of ASEAN diverse communities live together (Wong, 2018). In terms of ideology, the members are also diverse, ranging from socialist communist to religion-based governance. Despite all the differences, ASEAN unites its members. Its policies are sound not only for its member states, but also for its neighboring countries. ASEAN's extended foreign relations are necessary because the success of its policies also depends on the cooperation with outside parties. In this case, ASEAN has the potential to reach the international communities through its soft diplomacy power.

By these facilitating and mediating roles, ASEAN could maintain North Korea to be in the negotiation table while several multilateral frameworks with more powerful states failed. Even though that the complete denuclearization still requires more work from many relevant stakeholders, ASEAN engagement could increase the participation of North Korea in the issue. One most tangible signal is that North Korea admits that ASEAN peaceful and diplomatic effort has inspired North Korea to propose dialogue partnership with ASEAN, and currently on working-level progress (Annual Security Outlook, 2019).

\section{CONTEXTUALIZING THE ASEAN WAY AS A PEACEBUILDING FRAMEWORK IN KOREAN PENINSULA}

ASEAN way is never explicitly defined by ASEAN in a straightforward manner. This is exactly the culture of ASEAN countries where things are never really meant to be explicit. However, there are a few definitions have ever been mentioned by some public figures and scholars. Acharya defines ASEAN way as claims about a distinctive approach to dispute-settlement and regional cooperation developed by the members of ASEAN with a view to ensuring regional peace and stability (Acharya, 1997). For example, in a seminar in Kuala Lumpur, Rudolfo C Severino Jr., the Secretary General of ASEAN (1998-2002), said that Southeast Asians' way of conducts are manifestations of goodwill and the slow winning and giving of trust. Most scholars define ASEAN way based on two ASEAN characteristics, non-interference policy and consensus-decision making (Mahdi, Hafeznia, Ahmadipoor, \& Murphy, 2016). Other scholars conclude that ASEAN way is a symbol of ASEAN, where all ASEAN's policies 
are simply called the ASEAN Way, especially if the policy is distinct to the western countries' policies (Howe \& Park, 2017).

In the context of peacebuilding, the ASEAN way within which Asian cultures are embedded, become the principal means in resolving conflicts, both among ASEAN members and with the neighboring countries. In both situations, ASEAN will become the mediator among the conflicting parties. One of the most important qualities in being a mediator is impartiality, and ASEAN's fundamental principles agree with this. Both North and South Korea recognize this. ASEAN earns the trust from both countries and uses it as a capital in peacebuilding. In addition to this, ASEAN has Asian culture where being low profile is a virtue, so ASEAN does not announce its every move. As Rudolfo $C$ Severino said, the peacebuilding effort is quiet and under the radar. This is also what makes conflicting parties trust ASEAN. In the context on Korean Peninsula, ASEAN wins the hearts of the two countries by treating them with respect and dignity.

Meanwhile, the consensus-decision making policy contributes to the peacebuilding framework by highlighting equality among its members. Equality means justice. ASEAN is perceived to be fair and just because every member has the same right and voice. Equality may also mean that, if conflicting parties have a close relationship with one of the members, then they also establish a good relationship with the whole ASEAN member states. The voice of ASEAN is reached through collecting each member states' voice in the consensus decision-making policy. There is no veto that can unfairly dismiss the decision of the majority. There is no decision made if there is a single member state disagreeing with the motion.

\section{CONCLUSION}

The tension in Korean peninsula attract the world's attention as North Korea keeps to continue the nuclear program in which it is considered a threat for several countries such as United States of America and its allies. Among many parties who have been trying to broker the peace deal with the North Korea, ASEAN has managed to make both Koreas countries talk and kept the stability (so far) in the region. The unique role of ASEAN in the peacebuilding process is arguably succeeded by at least two factors; they are the ASEAN way and its traditional political capital toward both Koreas. Most scholars translated the ASEAN way simply as consensus-decision making policy and non-interference policy while the former secretary general of ASEAN, Rodolfo C Severino argues that ASEAN way is beyond the soft diplomacy where it gently takes care the dignity and sovereignty of each country in the very Southeast Asian way of cultures. Therefore, even though it took sometimes to be functioned, but it is worth waiting and sustainably lasts longer. Meanwhile, the traditional political capital is built since the formation of ASEAN by making-building peace among its founding fathers, making-building peace in the region with the rest of the countries (in the region), some are even becoming the members while some others are maintaining the good relationship or it is called traditional friendship. ASEAN might be relatively young in working formally as a peacebuilding agency, but its peacebuilding mission has been embedded within ASEAN since its formation, and its principal spirit remains the same until today, to keep (negative and positive) peace in the region. 
As seen from this paper, ASEAN does have much leverage in engaging with North Korea while at the same time, along with other parties, still have to work hard in achieving complete stability and denuclearization in Korean Peninsula. To accelerate the progress, this paper suggests ASEAN to continue the current progress in practically executing North Korea proposal to establish dialogue framework with ASEAN. Added by the fact that ASEAN has a closer access to talk to North Korea, ASEAN could develop more exclusive framework that resulted to more concrete denuclearization policies. ASEAN has the potential to convince North Korea that the sole purpose of these whole dialogues is for peace, instead of overthrowing North Korean regime. Since the main motivation of North Korea in developing warheads is for self-defense against United States, pacifying North Korea's insecurity will go accordingly with denuclearization progress. By this proposal, North Korea could be more comfortable for negotiation in the larger tables, such as under United Nations framework as well as to have more concrete bilateral deals with United States and/or South Korea.

However, we must understand that 'ASEAN way' will require quite a long time to function properly. Even then, only if we want to see it, because with the slow progress, success is usually hard to be seen. Unlike failure and bad news, they are easily accessed by the media to be reported so quickly throughout the world. For example, not many people know that ASEAN way is a miracle as stated by Kishore. When Samuel Huntington declared it was a clash of civilization, ASEAN provides a living laboratory of peaceful civilization coexistence by uniting differences ranging from communist countries to countries with a majority Muslim population. What happen to ASEAN countries in the past years will also be possible to happen in Asia-pacific region. ASEAN way can again show its magic in pacifying Korean Peninsula. A friend of ours from South Korea who we asked to review this article expressed her optimism with the hope that someday, she would be able to take his father to visit his hometown in North Korea. This article shows optimism along with her optimism and other millions of people both in North and South Korea on ASEAN's miracle to work (again) in the near future.

\section{REFERENCES}

A situation briefing for the diplomatic envoys of the ASEAN member states resident in the DPRK held. (2017, August 3). Retrieved from Ministry of Foreign Affairs of Democratic People's Republic of Korea: http://www.mfa.gov.kp/en/a-situationbriefing-for-the-diplomatic-envoys-of-the-asean-member-states-resident-in-thedprk-held/

Acharya, A. (1997). Ideas, Identity, and Institution-building: From the 'ASEAN Way' to the 'Asia-Pacific Way'? The Pacific Review, 319 - 346.

Ahn, M. S. (2010). The North Korea-Myanmar relationship: A historical perspective. Bulletin of The Atomic Scientist, 30-37.

Annual Security Outlook. (2018). Retrieved from ASEAN Regional Forum : http://aseanregionalforum.asean.org/wp-content/uploads/2019/01/ARF-AnnualSecurity-Outlook-2018-00000002.pdf 
Annual Security Outlook. (2019). Retrieved from ASEAN Regional Forum: http://aseanregionalforum.asean.org/wp-content/uploads/2019/08/FINALARFANNUAL-SECURITY-OUTLOOK-2019-1.pdf

Ariffin, E. (2019, February 24). South Korea's pivot to ASEAN. Retrieved from The ASEAN Post: https://theaseanpost.com/article/south-koreas-pivot-asean

ASEAN Regional Forum (ARF). (1994). Retrieved from ASEAN Official Website: https://asean.org/asean-political-security-community/asean-regional-forum-arf/

Au-Yong, R. (2019, June 23). ASEAN concerned about US-China trade war, focused on economic cooperation: PM Lee. Retrieved from Strait Times: https://www.straitstimes.com/asia/asean-concerned-about-us-china-trade-warfocused-on-economic-cooperation-pm-lee

Bhati, A. (2017, July 21). A Curious Relationship: Cambodia And North Korea. Retrieved from Mekong Research: https://www.mekongresearch.org/blog/2017/7/21/a-curious-relationshipcambodia-and-north-korea

Bhwana, P. (2019, December 22). Indonesia Gives Grant of Rp7.5 Billion to Help Myanmar Refugees. Retrieved from Tempo: https://en.tempo.co/read/1286655/indonesia-gives-grant-of-rp7-5-billion-to-helpmyanmar-refugees

Dunne, P. (2018, April 10). ASEAN may play key role in Korean Peninsula talks. Retrieved from Asia Times: https://asiatimes.com/2018/04/asean-may-play-keyrole-talks-korean-peninsula/

Favretto, K. (2009). Should Peacemakers Take Sides? Major Power Mediation, Coercion, and Bias. The American Political Science Review, 248-263.

Fisher, M. (2018, June 12). What Happened in the Trump-Kim Meeting and Why It Matters. Retrieved from New York Times: https://www.nytimes.com/2018/06/12/world/asia/trump-kim-meetinginterpreter.html

Galtung, J. (1996). Peace by peaceful means: Peace and conflict, development and civilization. London: SAGE Publications.

Galtung, J. (2000). Searching for Peace. Virginia: Pluto Press.

Ha, Y. S., Chung, K. J., \& Seo, J. S. (2016). An Analysis of Korea-ASEAN Trade and its Implications for the Shipping Industry in Korea. The Asian Journal of Shipping and Logistics, 63-71.

Haggar, S. \&. (2010). Sanctioning North Korea: The Political Economy of Denuclearization and Proliferation. Asian Survey, 539-568.

Heydarian, R. J. (2017). The Korea Crisis: Time for ASEAN To Play a Role. RSIS Commentary, 1-3. 
Howe, B., \& Park, M. J. (2017). The Evolution of the "ASEAN Way": Embracing Human Security Perspectives. Asia-Pacific Social Science Review, 1-15.

Jae-kyoung, K. (2016, July 27). ASEAN seeks Korean role in economic integration. Retrieved from The Korean Times: http://www.koreatimes.co.kr/www/news/biz/2016/07/488_210518.html

Jaehyon, L. (2019). Korea's New Southern Policy: Motivations of 'Peace Cooperation' and Implications for the Korean Peninsula. The Asian Institute for Policy Studies Issue Brief, 1-19.

Journal of Soviet Ambassador to the DPRK A.M Puzanov for 31 August 1957. (1957). Retrieved from http://digitalarchive.wilsoncenter.org/document/115657

Kaye, K. (1997). Workplace Wars and How to End Them: Turning Personal Conflicts into Productive Teamwork. New York: American Management Association.

Lederach, J. P. (2003). The little book of conflict transformation. Pennsylvania: Good Books.

Mahbubani, K., \& Sng, J. (2017). The ASEAN miracle: a catalyst for peace. Singapore: NUS Press: Ridge Books .

Mahdi, K., Hafeznia, M.-R., Ahmadipoor, Z., \& Murphy, A. B. (2016). ASEAN and Regional Peace in the South East Asia. International Journal of Humanities, 7593.

Nah, L. T. (2017). ASEAN and North Korea's Nuclear and Missile Programs. North Korean Review, 66-73.

Nye, J. S. (2008). Public Diplomacy and Soft Power. The Annuals of American Academy, 94-109.

Overview of ASEAN-Republic of Korea Dialogue Relations. (2020, February 14). Retrieved from https://asean.org/storage/2012/05/Overview-ASEAN-ROKDialogue-Relations-as-of-14-February-2020.pdf

Rivett-Carnac, M. (2015, October 9). Kim Jong Un Has Won a Real Statesperson Prize From a Nation That Is Not North Korea. Retrieved from Time: https://time.com/4067670/north-korea-kim-jong-un-award-indonesia-sukarno/

Salim, T. (2017, August 5). ASEAN encourages contributions from North Korea in ARF. Retrieved from The Jakarta Post: https://www.thejakartapost.com/news/2017/08/05/asean-encouragescontributions-from-north-korea-in-arf.html

Sengdara, S. (2019, June 21). Laos, DPRK diplomats confident of strengthening longstanding relationship. Retrieved from Asia News Network: http://annx.asianews.network/content/laos-dprk-diplomats-confidentstrengthening-longstanding-relationship-98858 
Severino, R. C. (2001, February). ASEAN: Building the Peace in Southeast Asia. Retrieved from ASEAN Official Website: https://asean.org/?static_post=aseanbuilding-the-peace-in-southeast-asia-2

Severino, R. C. (2001, September 3). The ASEAN Way and the Rule of Law. Retrieved from ASEAN Official Website: https://asean.org/?static_post=the-asean-wayand-the-rule-of-law

Vannarith, C. (2019, February). Cambodia-North Korea Relations. East-West Center Asia Pacific Bulletin, 1-14. Retrieved from https://www.eastwestcenter.org/publications/cambodia-north-korea-relations

Webel, C., \& Galtung, J. (2007). Handbook of Peace and Conflict Studies. Abingdon: Routledge.

Wong, C. H., Venkat, P., \& Cheng, J. (2018, June 6). Singapore Gears Up for the Greatest Show on Earth: The Trump-Kim Summit. Retrieved from The Wall Street Journal: https://www.wsj.com/articles/singapore-gears-up-for-thegreatest-show-on-earth-the-trump-kim-summit-1528277403

Wong, K. (2018, July 13). ASEAN should continue to help bring peace by embracing North Korea: Moon Jae-in. Retrieved from Mothership: https://mothership.sg/2018/07/asean-north-korea-moon-jae-in/

Young, B. (2019). The Origins of North Korea-Vietnam Solidarity. North Korea International Documentation Project Working Paper, 1-14.

Zwirko, C. (2019, May 10). North Korean, Lao high courts sign MOU on exchange and cooperation: KCNA. Retrieved from NK News - North Korea News: https://www.nknews.org/2019/05/north-korean-lao-high-courts-sign-mou-onexchange-and-cooperation-kcna/ 